\title{
Economic Science and Evolution of Economic Agents' Expectations Formation Process
}

\author{
Valeriy Shlychkov ${ }^{1} \&$ Diana Nestulaeva ${ }^{2}$ \\ ${ }^{1}$ Kazan National Research Technical University named after A. N. Tupolev, Russian Federation \\ ${ }^{2}$ Kazan State Power Engineering University, Kazan, Russian Federation \\ Correspondence: Valeriy Shlychkov, K. Marx str., 10, Kazan, 420111, Russian Federation.
}

\author{
Received: February 27, 2015 Accepted: April 3, 2015 Online Published: July 30, 2015 \\ doi:10.5539/ass.v11n19p82 URL: http://dx.doi.org/10.5539/ass.v11n19p82
}

\begin{abstract}
This paper gives a look-back study of the development of economic thought and considers the correlation dependency between the level of economic system's development and adequacy of economic views and concepts dominating in certain historic periods. The evolution processes of economic agents' expectations are analyzed together with the transformation of requests of economic subjects in connection with gaining economic knowledge in the situation of changing technological modes and developing economic systems.
\end{abstract}

Keywords: expectation, needs, economic science, economic agent, concept, paradigm, theory, scholar school

\section{Introduction}

Since the origin and at all the stages of its development, mankind has always had to pay close attention to the economic activity as it was directly related to the survival of humans as the dominating biological species on the planet. Empirical knowledge about economic activity was successively accumulated and systemized while the experience obtained was generalized and handed down from generation to generation in the form of customs, traditions, unwritten law and procedures which were later formalized and made out in the form of regulations and laws.

Having accumulated, throughout its history, a great volume of economic knowledge and having analyzed it, the society realized its economic goals and concerns, initially formulated them as separate concepts and postulations, on the ground of which the first rules of economic behavior of economic agents were developed. Since that, mankind, based on evolving economic thought, began exercising purposive economic policy, in an effort, first intuitive and then intended, to choose the most productive and optimal variants of behavior ensuring maximal economic effect from its activities.

Further establishing of society's socio-economic system in the conditions of complicating economic processes, growth of economic activity, organization of new and restructuring of existing markets greatly changed the role and increased the impact level of the economic science on the real sector of economy and the behavior of economic agents (Bataikin, 2012). On the background of grown public expectations, the range of issues brought up by the human society to research economists widened greatly and changed in a quality manner. If, at the initial stages of civilizational development, economic objects were meeting their needs in economic knowledge under the general epistemology, receiving relatively simple explanations and recommendations, currently this task is tried to be solved by the separate branch of science-economic theory, already operating multifunctional and multilevel economic and mathematical models understandable after special training and education which does not always meets the requests of economic agents.

Great Economic dictionary treats "expectation" as a situation in which the behavior of subjects of market economic system (decision-makers) depends not only on the events which took place in the past or are taking place now but also on expecting what may happen" (Azriliyan, 2010, p. 626). As we see, the authors are trying to explain the term "expectation" through "expecting what may happen", which, as we opine, is not quite correct. We offer to treat "economic agents' expectation" as their view of future economic events or evolution of some or other economic processes, meantime, public expectations from the economic science should be considered as society's established need for scientifically-based economic knowledge which will allow the economic agents to give unbiased assessment of the current socio-economic processes, timely response to the challenges arising in 
connection with the changes of economic reality by making adequate and efficient economic decisions.

\section{Methodology}

The methodological basis of the research conducted relied upon the integration of logical and historical approaches. The authors used widely applicable research methods-descriptive, analysis and synthesis, deduction and induction, generalization, observation, prognostication, scientific abstraction, statistical analysis, system analysis and grouping and classification methods, comparative historical and inter-industry analysis, expert judgments. The complex of those methods allowed the authors to ensure reliability of the research conducted and reasonability of its conclusions.

The information basis of the research included Russian and foreign works in philosophy, general economic theory, history of economic thought, institutional economic theory, etc., materials of scientific conferences and seminars, scientific reports of Institute of Economics, RAS (Russian Academy of Sciences).

\section{Results}

\subsection{Rise of Economic Thought}

Back in ancient Babylon in XVIII century BC, in Hammurabi Codex which survived unchanged to this day and is an inappreciable source of the law of the ancient East we see some examples of purposive regulation of society's economic life via adoption and application of legal norms and procedures. Even brief analysis of Hammurabi's Codex shows that it contains some elements of well-thought state policy aimed at the protection of existing state system and national economy while the legal norms worded therein logically and successively match the economic concept of slave owing society development, dominating in that period. The legislator, on one hand, legally declared the supremacy and priority of the crown, and, on the other hand, stimulated and encouraged the development of private initiative via the system of assignment into conventional holding of land, trade institutions and craft shops to state servants and warriors as rewards for due and steady-going service, thus establishing and strengthening the socio-economic foundation of his power. The leading and, as we would say now, "budget-generating" economic sector-crop farming-was regulated by state via fixed lease rates, for cropland- $1 / 3$ of the harvest, for garden mold- $2 / 3$ of the harvest. Meantime, in the event of bad harvest, those laws fully exempted leaseholders from the liability in connection with payment of lease which minimized economic risks of farmers and guaranteed their freedom, prohibiting lessors to make them debt-slaves in the conditions of natural force majeure. Commodity-money exchange was regulated by laws via restrictions of the margin of moneylenders, exercising the functions of the contemporary banking system.

Similar approaches to the regulation of society's economic life via philosophical and legislature-related activities are observed in ancient China and India (Confucius, about 551-479 BC; Meng-tzu, about 372-289 BC; Wise Brahman, about IV-III centuries BC).

Thus, even forty centuries ago the human society tried to maintain the stability of its national economic and political system, purposively effecting the behavior of economic agents and setting the balance between the basic factors of production, ensuring its development under the economic order existing at that time. Meantime, it should be noted that in the situation of subsistence economy and dominating crop farming which was fully dependent on climatic conditions and seasonal factors, we see extremely low (according to the contemporary standards) intensiveness of economic life and business activity of economic agents which greatly narrowed down the range of theoretical issues and problems arising in the course of economic activity. In the situation of localized economic systems and limited number of economically active agents, the society did not have the request for the establishment of overall economic doctrine, as separate economic views dominating in that historical period fully met the needs for economic knowledge.

\subsection{Rise and Evolution of European Economic Thought. Pre-Market Economic Concepts}

The rise of European economic thought and its further evolution happened in Ancient Greece and Ancient Rome where economic matters were also reflected in the works by thinkers and philosophers (Lycurgus, about IX-VIII century BC; Solon, between 640 and 635-about 559 BC; Aristotle, 384-322 BC; etc.). It was during those times when land titles were formalized and registered (laws of Dracontius dated $621 \mathrm{BC}$ ), which were interpreted in triplicate in further Roman law-right, title and interest; it was prohibited to enslave free citizens into debt-serfdom and property qualification was introduced (Solon); "natural laws" were worded which later laid the foundation for a number of economic doctrines and concepts, the relevance of which remained in effect down to our days. Definitely, "natural laws' allowed the ancient world's thinkers to divide people by professional and social statuses under the existing economic order of the society.

Further, those "natural laws" laid the foundation for medieval economic concepts which were identified with the 
will of God in Christian Europe and in the works by eastern philosophers were based on Quran's canons. Medieval philosophers created the theory of "fair price" (St. Augustine, 354-430), determined the approaches to "cost of labor" and "function of money" (Muhammad, 1332-1406), while the following terms were brought into scientific use: "division of labor" "wealth", "fair price", "labor input", "payment for risk", etc. (Bartenev, 2007; Blaug, 1994; Bulgakov, 2007), which served as a great contribution to the establishment of theoretical and methodological basis of the economic science in future. Medieval thinkers in general quite successfully managed to give theoretical explanation of economic processes flowing in the feudal society, and being mostly theologians, were able in their works to balance the interests of the most economically active part of society, the state, and mainly the church, having then dominant influence on socio-political life. Despite the activation of economic processes, the feudal society did not claim for development of any plans or, as we would say now, there was no business planning process. According to the existing traditions, economic agents in the course of economic decision-making addressed not economists but astrologists and stargazers which were sufficiently represented in each royal court and in each city, making their judgments based on the will of supreme forces.

\subsection{Establishment of Theoretical and Methodological Foundation for the Economic Science in the Course of Transition toward Market Economy}

Later, the development process of the economic thought was going in ethical direction under the evolution of socio-economic system of society itself, together going through stability stages and periods of revolutionary transformations and crises. In course of time, the change of economic order, shifts in productive forces and production relations development, formation of markets and new economic system, finished in early XVI century, called for innovative approaches to the study of flowing economic processes and quality improvement of scientific research and developments in national economy. Fragmented knowledge and separate economic concepts were no more able to meet the economic knowledge needs of agents and adequately response to the challenges arising in economy. There was arising the need to create a separate group of research scientists professionally engaged in the matters of society's economic life, capable to offer a universal economic theory of its development, using specific scientific methods and tools, i.e., we are saying about the establishment of economics as an independent science. Since that time, the economic thought, deemed earlier a part of philosophy, began to develop independently as a new social and political science.

As opined by some scientists, economics as a separate branch of scientific knowledge begins since 1615-the moment of printing the first scientific work recognized as a full scientific tractate. In that book, "Traicté de l'œuconomie politique" (Montchrétien, 1889) a French nobleman Antoine de Montchrétien (1575-1621) was the first to use the term "political economy", having given economics a name as to a science, under which it existed till the late XIX century. Meantime, in the academic community there are other approaches and opinions regarding the history of the economic science and the time of its rise as an independent branch. A famous economist and philosopher Daniel Hausman opines that "the economic science rose in XVIII century" and "it begins with the works of French physiocrats, Cantillon and Hume and especially Adam Smith". As he opined, "economic theory was born when people recognized the existence of economic mechanisms and systems which may be studied", and "basic efforts of economic theoretical thinking were yet spent on understanding of the capitalist economy" (Hausman, 2012, p. 36). Under this research we will not continue this discussion or support any party's position as we do not think that the exact date of the rise of economics as a science is of principal concern. Which is more important for us is the acceptance by all the parties of that discussion of the fact that economics in XXI century is a young and independent science at the initial development stages.

\subsection{The First Fundamental Directions of the Economic Science}

Doing their first steps, research economists offered the society two theories pretending for the universal status-mercantilism and physiocracy. Early mercantilism as the first direction of the economic science was formed in XVI century on the basis of active monetary balance concept which, on one hand, came to the ban of import of finished products and export of resources and money, and on the other hand, to the stimulation of import of those resources and money from outside and export of finished products. During late mercantilism period in XVII-XVIII centuries, the concept of active trade balance became dominating in the economic science, with the gist in the need for excess of revenues from export over import costs (Bartenev, 2007; Blaug, 1994; Bulgakov, 2007). Theoretical and methodological basis of mercantilism was laid by the works of G. Scaruffi (1519-1584), W. Stafford (1554-1612), T. Man (1571-1641), J.-B. Colbert (1619-1683) and others. That was a rather dissimilar system of views reflecting the concerns of mercantile capital, state and army in the Age of Discovery and intensive development of international trade. Mercantilists brought into use the following terms: "state protectionism", "duty", "quotas" and developed metallist and quantity theories of money. 
Physiocrats, like mercantilists, were reasoned from the natural order principle and were engaged in the development of economic laws of wealth origin and growth, procedures and principles of its distribution, based on the postulation that wealth growth due to natural factors is possible in agriculture only. As they opined, only land may bring the income in excess of initial costs and only in crop farming "net product" may exist, while in craft only change of matter but not growth may occur (Shlychkov, 2014). Meantime, in their works, physiocrats actually defended the interests of not only agrarians but also theoretically reasoned the need for development of market, capitalist relations in the condition of state's non-interference in businesses of economic agents. The founder of physiocracy is Francois Quesnay (1694-1774), who contributed to the economic science with the model of commodities and money turnover on national economy's scale. The tables offered by him divided the society into classes based on their role in the production process which actually was the first attempt of scientific macroanalysis where numerous variables were reduced to integrated parameters.

\subsection{Classic School of Political Economy, Marginalism and Institutionalism}

In the second half of XVIII century, in the course of breakthroughs in economy and the industrial revolution which ensured higher income from production compared to trade, a new doctrine of the economic science rose-liberalism or, as it is often called,-classic political economy. Capital was trying to escape from strict control by the state and therefore the basic and dominating postulation of the classic school became the concept of economic liberalism based on the principles of state's non-interference in economic processes, unlimited freedom of competition (invisible hand of the market), priority of individual interests over public (homo economicus model). The theoretical basis of the classic school was laid in the works of the following famous scientists: W. Petty (1623-1687), A. Turgot (1727-1781), A. Smith (1723-1790), D. Ricardo (1772-1823), J.-B. Say (1767-1842), J.R. McCulloch (1789-1864), F. Bastiat (1801-1850), T. Malthus (1766-1834), J.S. Mill (1806-1873), K. Marx (1818-1883). They developed labor theory of value, theories of division of labor, taxation, "golden standard", differentiated rent; laid down the law of diminishing returns; offered concepts of homo economicus and invisible hand of the market, divided value into natural and market, production capital into fixed and floating, etc. Such great contribution of classic political economy in the formation of theoretical and methodological foundation of the economic science and growing impact on the economic life of the society allowed to recognize liberalism a mainstream thing, which it remained till the end of XIX century (Shlychkov, 2014).

Marginalists became the main competitors of classic political economy creating a new school in the economic science and a new course of study-"economics". Marginalist revolution of the 1870s became the commencement of transition to a new paradigm of economic research-from the classical political economy to the marginal utility theory. The new theory was substantiated by the works of F. Galiani (1728-1789), J. Dupuit (1804-1866), A. Cournot (1801-1877), I. Thünen (1783-1850), G. Gossen (1810-1858), K. Menger (1840-1921), E. Böhm-Bawerk (1851-1914), F. Wieser (1851-1926), W. Jevons (1835-1882), L. Walras (1834-1910). Later, A. Marshall (1842-1924) in the UK, J.B. Clark (1847-1938) in the USA, V. Pareto (1848-1923) in Italy finished the formation of scientific and methodological foundation of the new marginalist doctrine combining the basic ideas of marginalism with some provisions of classic political economy, having created the neoclassic doctrine which since the end of XIX century has become the dominant direction in the economic science, giving birth to the contemporary "mainstream economics".

Actually, economics turned a science about choice and rational behavior of people in any spheres of public life. Marginalists, analyzing the processes in the real sector of economy, commenced the application of a new methodology based on marginal values while the leading principle of marginal analysis became choice and optimization, meantime, the study of general condition of the economy was started using balanced analysis method.

In XVII-XIX centuries there was one more independent school of the economic science-institutional economy or institutionalism occupying a specific position in the economic science and life, ensuring permanent and rather peaceful coexistence with all mainstream theories.

Institutionalism concept should be studied from the two points. On one hand, there are "institutions"-accepted socially norms of behavior, traditions and customs, on the other hand, there is fixing of those norms, traditions and customs in form of laws, entities and organizations, i.e., "institutes" which are designed for their use in real human lives. As the subject of their research, institutionalists announced the processes of institutional impact on society's economic life. Meantime, that economic school was unable to create own methodology which, as some scientists opine, is a trace of weakness. Early institutionalism began forming as an independent theory in the beginning of XX century. For the coming hundred years, there were Anglo-American institutionalism 
(represented by T. Veblen, J. Hobson, J. Commons, W. Mitchell); American institutionalism (W. Rostow, J. Galbraith, D. Bell, A. Toffler); neoinstitutionalism (R. Coase, O. Williamson, A. Alchian, H. Demsetz).

By the end of XX century, under the new economics paradigm, three basic directions were formed in science: classic political economy, marginalism and institutional economic theory which, along with mercantilists and physiocrats, became the foundation and starting point for the development of all other paradigms, schools, concepts and doctrines (Shlyuchkov, 2014; Shlyuchkov \& Nestulaeva, 2013).

\subsection{Contemporary Economics of XXI Century}

Contemporary economics of XXI century which picked up the torch is called "modeling science" (Colander, 2011, p. 63), and there "reign neoclassic microeconomics, macroeconomics and econometrics" (Hausman, 2012, p. 46). Governed by J.M. Keynes's postulation, "when facts change I change my ideas" (Keynes, 2007) and responding to the changes of public requests, the academic economic community is currently reviewing the research directions and basic theoretical principles of the contemporary science (Kirman, Colander, \& Felmer, 2010 , p. 25). Now economic theory brings up the task "to join, to stick the core units of mainstream theory with units of post-Keynesian and behavioral theory in an attempt to shift from determinism methodology to relativism, from rationalism to psychologism, from single-level to multi-level analysis" (Olsevich, 2012; Olsevich, 2013 , p. 9).

In the current post-industrial epoch, the number of economically active agents has increased greatly, independently making innovative economic decisions beyond the limits of the present and typical economic activity, which brought the request for other quality, deeper scientific analysis of economic processes. Meantime, economic theory itself began to influence the process of public expectations, as its research results in the information society are quickly becoming available for economic agents and have great impact on their behavior, formation of their ways of thinking, and motivations for acting, as well as for developing public expectations towards science itself.

\subsection{Role and Place of the Economic Science in the System of Social and Political Sciences}

The process of identification of economic theory as an independent science by the academic community has been going throughout the whole period of its history and has not been finished yet. From not only other scientists, but from economists as well we can hear statements on "ambivalent status of economics" and various points of view on the role and place of economics in the system of public sciences. The academic community demonstrated so wide variety of views on the point that any unprepared person virtually would fail to build own point of view. The range of statements by scientists on the role and place of economic theory in the system of public sciences spread from admitting it the "top" of social sciences to "pseudoscience". In the meantime, similar processes occurred and are occurring on the background of lack of consensus between researchers on the basis crucial problems of economic science which became, as we opine, one of the distinctive features of economic theory, as fellow economists have not managed to find common approaches in fundamental issues in connection with determination of economic science's research subject and methods of research as well as limits of understanding economic processes.

Economists have always been making efforts to get their science recognized as an independent branch of scientific knowledge by both the academic community and public. In an attempt to raise the prestige of economic science, they managed to achieve a separate nomination under the most prestigious global prize-Nobel Prize which since 1969 has been awarded not only for scientific achievements in physics, chemistry, physiology and medicine but also for achievements in economics. However it should be noted that this prize is not the heritage of the great A. Nobel. Of course it is not a secret (although, not shown off) that this prize was established in honor of three hundred years' anniversary of Bank of Sweden and is funded by Bank while its official name is "Prize of Swedish state bank in economic sciences in memory of Alfred Nobel". The decision of Nobel Foundation board on establishment of that nomination was made contrary to objections of his direct ancestors referring to the deathbed will of A. Nobel who in his letters expressed negative attitude to economists and did not consider economics a separate science. However, the lobbyist capabilities of economists' community, their influence on business elites and political establishment of Scandinavian (and other) countries granted economic theory (yet, not through the front but through the back door) an honorable place among the sciences which no social science can pretend to, as Nobel Foundation made definite resolution on refusal from creating any other nominations.

Today the overwhelming part of the society and a great part of the academic community share the opinion of Daniel Hausman that "economics is a separate science" (Hausman, 2012) and it "achieved greater advancement than any other branch of social sciences, as it is more definite and exact than all other branches" (Marshal, 2007, 
p. 733). Economics is taught in all the largest educational institutions of the world and specialists directly related to economy are among the most prestigious and highly paid professionals making up a great part of the social elite, thus exerting much influence on political and economic life of any state, corporation or business entity.

\subsection{Formation of Public Expectations in the Course of Post-Industrial Society's Development}

As often happens, each event has its back side. In exchange for recognizing economic theory's status as a full science, the society brought its expectations to economists in connection with the practical results from their research, understandable for most people and formalized following other sciences, first of all, physics, which is recognized by the global scientific community as the etalon of natural sciences. It should be admitted that economists themselves were insufficiently effective in realizing the explanatory function of their science and were unable to create stable public understanding of the specifics of economics as a certain branch of scientific knowledge, arising out of its peculiarities and methodology and, mainly, from cognitive and psychological specifics of its subjects (Akerlof \& Schiller, 2010). Economists failed to explain to the public the fact that "economics is not a science in the sense that in the same conditions the same method may be applied regularly and the same results will be achieved" (Shoikher, 2005), while those results may not be formalized like multiplication table and have universal nature as the rapidly changing economic reality makes them true only in a short historical aspect.

Ideally, economic agents would like to receive from economists a sort of "Economic Bible"-a list of rules and laws, formalized procedures and time-tested guidelines, the use of which in public business and economic life would guarantee positive economic effect. Like heroes from the Russian fairy-tales standing on the crossroads, economic agents wish to early understand the risks waiting for them in the event of choosing some or other way, having evaluated pros and contras of other alternative challenges. However the economic science is now unable to build on the crossroads a milestone of exact knowledge and engrave on it the behavior rules guaranteeing business entities any desirable economic effect. Currently it is not only unable to create such universal instrument of regulation of economic agents' activities but also to offer to the public any generally accepted and overall economic theory. Actually, in the course of their research, economists are applying the principle of competing concepts and paradigms around which the representatives of the academic community are consolidated, manifesting various views and approaches to the fundamental issues of the economic science.

As it seems to us, the attempt to analyze and review the scientific results accumulated for many years and their unification in a code of laws, postulations and theories mutually exclusive and contradicting to each other, in practice may lead to creating "Books of Books". It will rather be a religious tractate then an economic one, as it will mostly be based on authors' faith and authority while the truth of most postulations and statements contained there will hardly be able to be proved by traditional scientific methods. Meantime, some chapters and sections of such "Economic Bible" created by various authors in various times will not be logically connected or arise out of each other and would rather be in a sort of internal conflict, as the fundamental assumptions laid down would contain mutually exclusive provisions.

\subsection{Economic Knowledge as a Factor of Social Development. Public Expectations}

It should be noted that parties of economic relations mainly claim the quality of prognostication function of the economic science, i.e., the capability of science to foresee and explain some or other changes in economy and timely respond to the challenges and contradictions of the economic reality via the procedure of developing science-based and, most significantly, efficient solutions of crucial problems which economic agents experience in the course of economic activity.

Meantime, the relationships between economic agents and economists see a trend when "common individuals are inclined to consider economists judging from the current economic situation and not from systematical assessment of economic theories" (Hausman, 2012), imposing the latters with the liability for all failures and faults of the economic policies of their states and governments as well as business entities, ignoring the fact that "science may not be liable for its use and any mistakes in connection therewith" (Plot, 2011, p. 17). That is why in public consciousness the crises of national economies of XIX-XX century and the global financial crisis of 2008-2009 are integrally linked with the crises of economic theory caused by the inconsistency of concepts, theories and applied methods with the real public economic life.

Not rejecting the fact of correlation dependency of the conditions in science and the real sector of economy, we fully share the point of view of professor O.S. Sukharev stating that "sharpening discussions on the scientific crisis and methodology are usually caused by growing pessimism in crisis periods and are in no way related to the true content and capabilities of the economic science-current and potential, facing the future" (Sukharev, 2014). Actually, economic agents, meeting any new and not always understandable economic challenges and 
processes during economic crises call for recommendations from scientists which in turn are not always able to timely offer adequate and scientifically rationalized solutions as "economic reality is too multivariate and the rate of its changes exceeds the rate of its study (Polterovich, 1997).

Any science and economic theory as well is developing oriented at the practical needs of the human society, and today economic scientists can hardly say that they are able to fully meet the expectations and public needs as a result of their scientific research. However, assessing the economic science, public should consider the fact that "fundamental research in other sciences is aimed at the solution of much simpler tasks, ...while the success of science is assessed as progress but not full achievement of some or other targets put forward" (Plot, 2011, p. 17). We see that in practice "the economic science is often assessed in the sense of achievement of economic targets brought by public or political process although such targets are often unachievable" (Plot, 2011, p. 16).

It should not be rejected that "fundamental economic studies have deep impact on our lifestyle" and that "economic science radically changes both our lifestyle and our political preferences" (Plot, 2011) In the meantime, economic theory still remains "a stepdaughter of applied science" in the public consciousness, causing a situation in which "other sciences are assigned more money annually than economic theory received for the whole human history, and such funding imbalance has been for dozens of years" (Plot, 2011). Thus, if we estimate in money the contribution of the fundamental economic science in public economic life, we will see that it is clearly underappreciated while public's requests in connection with science research are not supported by the assignment of relevant funding. We opine that public expectations from the economic science should be growing simultaneously with the public recognition of its contribution to human wealth and adequate assessment of its role in regulating the contemporary society's economic life. Economic theory must become a truly "social science" not only by the subject and object of the research but also by high level of support by the human society of its ideas, theories and by establishment of efficient tools for implementation of the science's research results in economic life.

\section{Conclusion}

Is it possibly to fully meet public need for knowledge by any science and economic theory in particular? As it seems to us, the question itself and any possible answers are within the classic philosophy and general epistemology, and in answering it we should understand first-is it possible in principle to meet the set of each personality's needs? We think that it is low probable as on the background of public opportunities growth and gradual satisfying of designated human needs we see the simultaneous process of growing requests, their extension and formation of new demands previously unknown. It means that in each separate period there will be a group of needs which is in principle impossible to meet because of imbalance of "public capabilities-personal needs" and continuous growth of potential demanders. Concerning the public needs for science knowledge, we opine that cognitive process is endless and the way of a scientific researcher is that of a traveller trying to reach the skyline. Meantime, neither direction, nor speed are effecting the time for reaching the target as the line is moving for the distance walked and still remains unreachable. Furthermore, if a researcher climbs a mountain in the course of study, where he can look at his way in binocular from a higher point, he will be able to see new, previously unknown details of the terrain and obstacles on the way. That new knowledge will assist him to choose the optimal route and make his way easier greatly but will not get him closer to the target, as it was initially chosen incorrectly. It is wrong to call the final goal of science collecting and analyzing scientific data and development of efficient solutions on that basis, because it is not the final goal but rather methods and ways to solve the intermediary tasks on the endless way. The goal of science, as we opine, should be the evolutionary development of our civilization, which is possible only through the accumulation of scientific knowledge required for adequate reaction to real and potential challenges and threats to human society arising both from the external environment and from existing internal contradictions.

In the same way the economic science, reacting to today's public expectations and requests, forms new theories, paradigms and methodology which allow to get answers only to some discussion questions. Science is in principle unable to submit to public the required volume of scientific knowledge enabling to draw full and unbiased view of the economic life and processes and to give answers to all available questions, as the speed of changes in society and its economic life does not let scientists to timely analyze the information obtained and synthesize new knowledge based on it. Practice shows that any scientific knowledge, especially economic, remains true only within a short term nowadays, and a scientific researcher will always be a step behind the economic reality, although reasonable and true prognostications in some cases will help him to keep ahead that reality, thus effecting its formation. If the issue of ensuring public economic life's efficiency is considered the main goal of the economic science, we opine that such goal is abstract and its achievement cannot be verified. Unfortunately, there are no strict criteria and comprehensive system of parameters ensuring quality and quantity 
assessment of that process and its impact on other kinds and spheres of human activities. Some or other economic decisions made by some economic agents may be highly efficient for them and at the same time harmful for the society. Finding balance of interests of economic agents and society is always very complex, as it is required to do analysis of the consequences of decisions made not only from the point of view of economic efficiency but also to assess socio-political, ecological and other risks which may often fully eliminate any possible economic effect. The economic science, providing scientific and theoretical follow-up of public economic activities, must put a task to form the expectations of economic agents on the principles of balance of individual and public interests. On its part, public must more definitely formulate its interests, bringing ambitious but realizable tasks, setting strict criteria ensuring unbiased control of their achievement.

\section{References}

Akerlof, G., \& Schiller, R. (2010). Spiritus Animalis, or How human psychology drives the economy, and why it matters for global capitalism. Moscow: Alpina Business Books.

Azriliyan, A. (2010). Grand economic dictionary. Moscow: Institute of new economics.

Bartenev, S. (2007). History of economic doctrines: textbook. Moscow: Magistr.

Bataikin, P. (2012). Influence of asymmetric information on development of markets in modern economy. The Review of economy, the law and sociology, 3.

Blaug, M. (1994). Economic theory in retrospect. Moscow: Delo LTD.

Bulgakov, S. (2007). History of economic and social doctrines. Moscow: AST; Astrel.

Colander, D. (2011, December). The MONIAC, Modeling and Macroeconomics. Economy Politica a XXVIII, numero special.

Hausman, D. (2012). Philosophy of economics. Anthology. Moscow: Gaidar Institute publishing.

Keynes, J. (2007). The General theory of employment, interest and money. Selecta. Moscow: Eksmo.

Kirman et al. (2010). Financial crisis and failures of contemporary economic science. Issues of economics, 6.

Marshal, A. (2007). Fundamentals of economic science. Moscow: Eksmo.

Montchrétien, A. (1889). Traicté de l'œuconomie politique: dédié en 1615 au Roy et la Reyne Mere du Roy. Paris: PLON, Nourrit.

Olsevich, Yu. (2012). Cognitive and psychological shift in axiomatic of the economic theory. Alternative hypotheses. Saint-Petersburg: Aleteiya.

Olsevich, Yu. (2013). Contemporary crisis of mainstream as assessed by its adepts (preliminary analysis). Moscow: Institute of economics, RAS.

Plot, Ch. (2011). General review: What do fundamental studies in economics give to us? How the economic science helps us to make our lives better. Moscow: Gaidar Institute publishing.

Polterovich, V. (1997). Crisis of the economic theory. Report at scientific seminar of Economics department and Central economic and mathematical institute of RAS "Unknown economy". Retrieved April 5, 2015, from http://www.nbrilev.ru/krizis_economic_theory_htm

Shlychkov, V. (2014). 400 years of evolution: from political economy to economics. The Review of economy, the law and sociology, 4.

Shlychkov, V., \& Nestulaeva D. (2013). The crisis of economic theory as a starting point of its further development. The Review of economy, the law and sociology, 4.

Shoikher, V. (2005). Anthology of wisdom. Moscow: Veche.

Sukharev, O. (2014). Methodology and capabilities of the economic science. Moscow: Infra-M.

\section{Copyrights}

Copyright for this article is retained by the author(s), with first publication rights granted to the journal.

This is an open-access article distributed under the terms and conditions of the Creative Commons Attribution license (http://creativecommons.org/licenses/by/3.0/). 